\title{
KARAKTERISTIK HANTARAN HIDROLIK JENUH TANAH PADA PERKEBUNAN KELAPA SAWIT, PTPN VII LAMPUNG SELATAN
}

\author{
Characterisitic of Soil Saturated Hydraulic Conductivity at Oil Palm \\ Plantation, PTPN VII South Lampung
}

\author{
Pungkas Syahadat1), Suria Darma Tarigan2)*, dan Kukuh Murtilaksono2) \\ 1) Alumni Departemen Ilmu Tanah dan Sumberdaya Lahan, Fakultas Pertanian IPB, J1. Meranti Kampus \\ IPB Darmaga Bogor 16680 \\ 2) Departemen Ilmu Tanah dan Sumberdaya Lahan, Fakultas Pertanian IPB, J1. Meranti Kampus IPB \\ Darmaga Bogor 16680
}

\begin{abstract}
Oil palm is the tree that has a high water requirement to grow. Water availability can be an important limiting factor for oil palm production. During dry season, oil palm relies on soil water storage for water supply. Soil saturated hydraulic conductivity influences amount of soil water storage. Objective of the research was to determine characteristic of soil saturated hydraulic conductivity in different locations in oil palm plantation including: palm circle, leaf frond piles and harvest path. The characteristic can be used to manage soil water storage under oil palm plantation for higher availablity. We found that soil saturated hydraulic conductivity in soil frond piles (dead path) was the highest among considered location (2.94-30.4 $\left.\mathrm{cm} \mathrm{h}^{-1}\right)$ followed by those in palm circle $\left(2.5-13.4 \mathrm{~cm} \mathrm{~h}^{-1}\right)$ and harvest path $\left(1.6-12.8 \mathrm{~cm} \mathrm{~h}^{-1}\right)$. High soil saturated hydraulic conductivity under leaf fronds piles was due to the preservation of good soil structure. Low soil saturated hydraulic conductivity in palm circle and harvest path were due to the frequent harvest activities which increased soil compaction in this particular area.
\end{abstract}

Keywords: Hydraulic conductivity, oil palm, water avaiability

\begin{abstract}
ABSTRAK
Kelapa sawit (Elais guineensis Jacq.) merupakan salah satu tanaman yang memerlukan air dalam jumlah yang banyak. Ketersediaan air merupakan salah satu faktor pembatas utama bagi produksi kelapa sawit. Pada musim kemarau kelapa sawit akan mengandalkan cadangan air bawah tanah untuk kebutuhan airnya. Hantaran hidrolik merupakan parameter sifat fisik tanah yang berperan dalam penambahan air bawah tanah. Tujuan dilakukannya penelitian ini adalah mengetahui karakteristik hantaran hidrolik jenuh pada berbagai jenis lokasi yang meliputi gawangan mati, piringan, dan jalan pikul pada perkebunan kelapa sawit PTPN VII Lampung. Karakteristik ini dapat dijadikan acuan pengelolaan lahan agar dapat meningkatkan cadangan air bawah tanah. Nilai hantaran hidrolik jenuh pada lokasi gawangan mati berkisar antara 2.9-30.4 cm jam $^{-1}$ dengan kelas sedang sampai sangat cepat, pada lokasi piringan berkisar antara $2.5-13.4 \mathrm{~cm} \mathrm{jam}^{-1}$ dengan kelas agak lambat sampai cepat, dan pada lokasi berupa jalan pikul nilai hantaran hidrolik jenuhnya berkisar antara $1.6-12.8 \mathrm{~cm}^{-1} \mathrm{~m}^{-1}$ yang berada pada kelas agak lambat sampai cepat. Tingginya hantaran hidrolik pada gawangan mati disebabkan terjaganya struktur tanah oleh tumpukan pelepah yang sudah mati. Hasil penelitian menunjukan bahwa aktifitas pemanenan yang intensif menurunkan nilai hantaran hidrolik jenuh tanah pada areal piringan dan jalan pikul tempat mengangkut hasil panen disebabkan peningkatan kepadatan tanah.
\end{abstract}

Kata kunci: Hantaran hidrolik, kelapa sawit, ketersediaan air

\section{PENDAHULUAN}

Perkebunan kelapa sawit di Indonesia saat ini sudah mencapai luasan 8 juta ha yang meliputi perkebunan rakyat, swasta dan BUMN. Kelapa sawit merupakan komoditas ekspor andalan di sektor perkebunan bagi Indonesia terutama dalam kurun waktu 20 tahun terakhir. Selain sebagai andalan ekspor, kelapa sawit juga digunakan sebagai sumber minyak nabati. Usaha kelapa sawit juga dijadikan sebagai gantungan hidup jutaan tenaga kerja perkebunan (Fauzi et al., 2002).

Pesatnya perkembangan ini dapat mengakibatkan penggunaan lahan yang tidak sesuai untuk kelapa sawit namun terus dipaksakan mengingat permintaan atas kebutuhan hasil olahan komoditas ini sangat tinggi. Ketidaksesuaian lahan tersebut dapat berakibat pada kurangnya daya dukung tanah terhadap pertumbuhan dan produksi kelapa sawit. Salah satu daya dukung utama untuk pertumbuhan dan produksi kelapa sawit adalah

*Penulis Korespondensi: Telp.0251-8629360 ; Email.surya.tarigan@yahoo.com 
ketersediaan air sepanjang tahun. Kelangkaan air di beberapa perkebunan kelapa sawit di Indonesia diakibatkan oleh menurunnya cadangan air bawah tanah. Penurunan cadangan air bawah tanah tersebut disebabkan oleh menurunnya kemampuan tanah meresapkan dan melalukan air (hantaran hidrolik) pada daerah tangkapan air sebagai akibat dari ketidaksesuaian penggunaan lahan dan pengelolaan lahan yang salah, serta tidak diterapkannya kaidah-kaidah konservasi tanah dan air yang sesuai (Murtilaksono et al., 2011).

Kelapa sawit mampu tumbuh pada berbagai jenis tanah, namun tidak pada tanah-tanah yang tergenang. Faktor lingkungan yang mempengaruhi pertumbuhan kelapa sawit antara lain iklim, topografi, dan tanah. Faktor iklim berhubungan dengan curah hujan. Kelapa sawit merupakan tanaman yang memerlukan banyak air sehingga diperlukan curah hujan yang tinggi untuk memenuhi kebutuhannya. Curah hujan yang baik untuk pertumbuhan kelapa sawit berkisar antara 1250-3000 mm per tahun dengan bulan kering kurang dari 3 bulan (Murtilaksono et al., 2007). Suhu yang baik untuk pertumbuhan kelapa sawit berkisar pada $22-33{ }^{0} \mathrm{C}$ dengan kelembaban udara relatif 50-90\% (Pahan, 2008). Faktor topografi akan berpengaruh kepada kemudahan dalam panen, pembuatan jaringan jalan, dan keefektifan pemupukan. Bentuk wilayah yang sesuai untuk kelapa sawit adalah datar sampai datar berombak yaitu wilayah dengan kemiringan 0-8\%. Untuk wilayah dengan kemiringan lereng 8-30\% kelapa sawit masih dapat tumbuh dan berproduksi dengan baik dengan memberikan upaya pengelolaan tertentu seperti pembuatan teras. Faktor berikutnya adalah faktor tanah, yang meliputi kimia, fisika, dan biologi tanah. Faktor kimia dan biologi tanah kurang begitu diperhatikan karena kemampuan kelapa sawit yang mampu tumbuh pada berbagai jenis tanah. Sifat fisik tanah memiliki peranan penting dalam produksi kelapa sawit terutama jika dihubungkan dengan kemampuan tanah untuk menyimpan air (Sunarti et al., 2008). Tanaman kelapa sawit dapat tumbuh di berbagai jenis tanah, seperti podsolik, latosol, alluvial dan regosol. Selain itu kelapa sawit membutuhkan sifat fisik tanah yang baik seperti tekstur tanah ringan dengan kandungan pasir 20-60\%, debu $10-40 \%$, dan liat $20-50 \%$. Tanah yang kurang cocok adalah tanah berpasir, tanah gambut tebal, adanya lapisan padas, dan struktur tanah yang buruk (Yahya, 1990).

Hantaran hidrolik merupakan salah satu sifat fisik tanah yang berpengaruh langsung terhadap ketersediaan air bawah tanah. Hantaran hidrolik memiliki nilai yang beragam pada tiap jenis tanah. Karakteristik sifat fisik tanah khususnya mengenai hantaran hidrolik tanah sebagai akibat dari pengelolaan lahan di perkebunan kelapa sawit masih belum banyak diketahui. Penelitian ini bertujuan mengetahui karakteristik hantaran hidrolik jenuh pada beberapa jenis lokasi yang meliputi gawangan mati, piringan, dan jalan pikul serta posisi lereng pada perkebunan kelapa sawit PTPN VII Lampung.

\section{BAHAN DAN METODE}

Penelitian ini dilakukan di kebun kelapa sawit PTPN VII Unit Usaha Rejosari, Lampung Selatan. Penelitian dilakukan pada saat tanaman kelapa sawit berumur 12 tahun. Tempat pengukuran hantaran hidrolik jenuh dibagi menjadi tiga blok sebagai ulangan, tiap blok dibagi menjadi tiga tempat yaitu, lokasi atas, lokasi tengah, dan lokasi bawah. Pada masing-masing lokasi diambil tiga tempat lagi yaitu, gawangan mati, piringan, dan jalan pikul. Macam tanah di lokasi penelitian menurut klasifikasi Dudal-Soepraptohardjo adalah Podsolik Merah Kuning, sedangkan menurut klasifikasi USDA merupakan jenis Typic Kanhapludult untuk lereng atas dan tengah serta Fluventic Dystropept untuk lereng bawah (Tim Faperta IPB-PPKS Medan, 2006). Secara keseluruhan kisaran tekstur pada lokasi penelitian berkisar dari lempung sampai liat.

\section{Bahan dan Alat}

Bahan yang digunakan adalah air, yang digunakan untuk penetapan hantaran hidrolik jenuh. Air yang digunakan dalam pengukuran ini berasal dari sumur, sungai dan sumber-sumber air lain yang dekat dengan lokasi pengukuran.

Alat-alat yang digunakan adalah bor belgi, permeameter, tissue, stop watch, ember, gayung yang digunakan dalam pengukuran hantaran hidrolik jenuh.

\section{Metode}

\section{Penentuan Titik Pengukuran di Lapangan}

Titik pengukuran di lapangan ditentukan berdasarkan jenis lokasi seperti gawangan mati, piringan, dan jalan pikul. Pengukuran dilakukan pada titik-titik yang ditentukan secara acak pada tiap lokasinya. Pada lokasi atas dilakukan pada tiga lokasi yaitu gawangan mati, piringan, dan jalan pikul yang masing-masing diulang sebanyak tiga kali. Gawangan mati merupakan daerah yang terletak diantara dua baris pohon kelapa sawit yang umumnya belum mengalami pengolahan ataupun ganguan fisik. Piringan merupakan daerah berbentuk lingkaran yang mengitari pohon kelapa sawit. Daerah ini merupakan daerah dimana pupuk ditebar, dan biasanya daerah ini bersih dari gulma. Jalan pikul merupakan daerah yang digunakan untuk pengangkutan hasil panen yang merupakan daerah di antara baris kelapa sawit pada gawangan hidup. Titik pengukuran juga dibedakan berdasarkan posisinya pada lereng, yaitu lokasi atas, lokasi tengah, dan lokasi bawah yang masing-masing memiliki tiga jenis lokasi lahan. Dengan demikian tempat pengukuran akan terbagi menjadi lokasi atas (gawangan mati, piringan, jalan pikul), lokasi tengah (gawangan mati, piringan, jalan pikul), dan lokasi bawah (gawangan mati, piringan, jalan pikul) pada tiap-tiap bloknya. Setiap lokasi dilakukan pengukuran sebanyak tiga kali sebagai ulangan dengan demikian jumlah pengukuran adalah 3 (gawangan mati, piringan, dan jalan pikul) x 3 (lereng atas, tengah, dan bawah) $\times 3$ (ulangan) $=27$ titik pengukuran . 


\section{Pengukuran Hantaran Hidrolik Tanah}

Metode yang digunakan dalam pengukuran hantaran hidrolik adalah Shallow Well Pump-In. Titik pada lokasi yang diukur diambil secara acak, lalu titik tersebut dilubangi sedalam $20 \mathrm{~cm}$ dengan menggunakan bor belgi. Alat permeameter diisi air sampai penuh, kemudian pada ujungnya ditutup dengan kertas tisu. Lubang yang telah dibuat di tanah diisi air hingga penuh, lalu permeameter dimasukan ke dalam lubang tersebut. Kran dibuka pada ujung permeameter agar air di dalam permeameter mulai turun. Penurunan air tersebut dicatat per satuan waktu tertentu. Pengukuran terus dilakukan sampai mencapai keadaan konstan, yaitu pada saat air yang turun pada permeameter dengan kecepatan tetap. Hal ini merupakan kondisi dimana tanah di dalamnya sudah jenuh air.

\section{Analisis Data}

Data hantaran hidrolik yang didapat dari pengukuran di lapangan diplotkan ke dalam kurva hubungan laju penurunan air dengan waktu yang kemudian dibuat trade line-nya untuk memperoleh pola hantaran hidroliknya secara umum.

Untuk menghitung hantaran hidrolik jenuhnya digunakan persamaan (Baver, 1959):

$$
K=\frac{\left\{\ln \left(h / r+\left[(h / r)^{2}+1\right]^{1 / 2}\right)-1\right\} Q}{2 \pi h^{2}}
$$

$\begin{array}{ll}\text { K } & =\text { Hantaran Hidrolik Jenuh } \\ \mathrm{R} & =\text { Jari-jari Lubang } \\ \mathrm{H} & =\text { Tinggi Muka Air } \\ \mathrm{Q} & =\text { Debit Air }=\text { A.V } \\ \mathrm{A} & =\text { Luas Tabung Permeameter } \\ \mathrm{V} & =\text { Laju } \\ \pi & =3.14\end{array}$

\section{HASIL DAN PEMBAHASAN}

\section{Hantaran Hidrolik}

Pada awal pengukuran nilai hantaran hidrolik cenderung lebih besar jika dibandingkan dengan pada akhir pengukuran. Hal ini dikarenakan pada awal pengukuran pergerakan air di dalam tanah dipengaruhi oleh gaya gravitasi dan gaya hisapan matriks. Seiring dengan kondisi tanah yang makin lama akan semakin jenuh maka pengaruh gaya hisapan matriks akan semakin berkurang dan lama kelamaan gaya yang bekerja hanya gaya gravitasi saja, oleh sebab itu nilai hantaran hidrolik akan semakin menurun. Setelah tanah jenuh maka nilai hantaran hidrolik menjadi konstan, dan nilai yang disebut hantaran hidrolik jenuh tanah.

Jika dilihat rataan hantaran hidrolik dari tiap Blok, nilai hantaran hidrolik jenuh terbesar terdapat pada Blok 3 dengan nilai $19.1 \mathrm{~cm} \mathrm{jam}^{-1}$ lalu Blok 1 dengan nilai $6.77 \mathrm{~cm} \mathrm{jam}^{-1}$, dan yang terkecil adalah pada Blok 2 dengan nilai $2.33 \mathrm{~cm} \mathrm{jam}^{-1}$, dan masing-masing Blok termasuk ke dalam kelas cepat, agak cepat, dan sedang (Gambar 1).

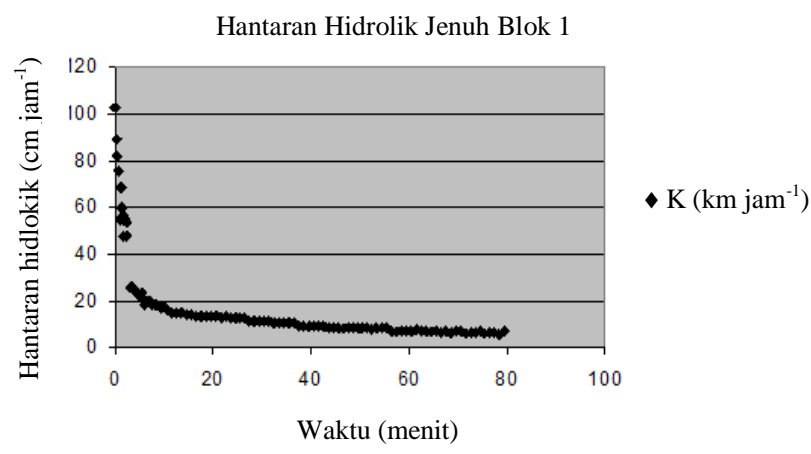

Hantaran Hidrolik Jenuh Blok 2

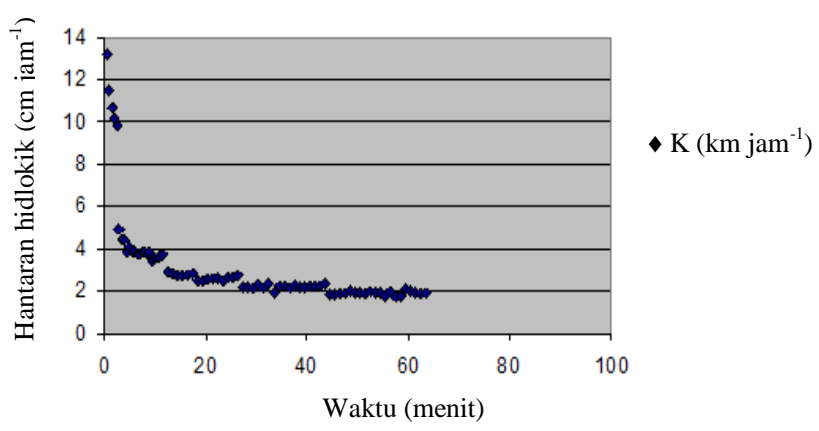

Hantaran Hidrolik Jenuh Blok 3

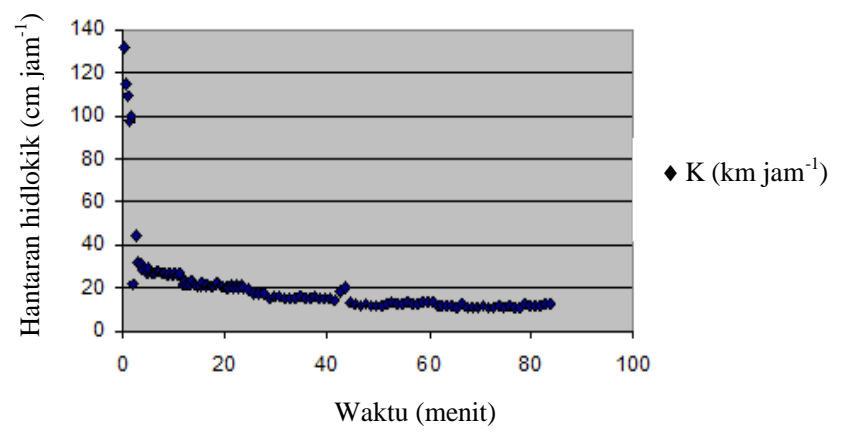

Gambar 1. Rataan hantaran hidrolik jenuh pada piringan, gawangan mati dan jalan pikul untuk masingmasing blok

Tekstur dan porositas tanah merupakan salah satu faktor yang mempengaruhi hantaran hidrolik jenuh tanah. Jika dibandingkan nilai porositas antar blok, blok 3 memiliki nilai yang lebih tinggi, kemudian diikuti oleh blok 1 dan kemudian blok 2. Nilai porositas pada blok 3 adalah $62.1 \%$ pada blok 1 adalah $57.7 \%$ dan pada blok 1 adalah 56.2\% (Tabel 1). Tingginya nilai hantaran hidrolik jenuh tanah pada Blok 3 dipengaruhi oleh pori drainase sangat cepat dan cepat yang tinggi.

Tabel 1 menunjukkan tanah yang berada pada tanah bagian atas memiliki porositas yang lebih tinggi jika dibandingkan dengan tanah-tanah yang berada dibawahnya. Hal ini sejalan dengan nilai hantaran hidrolik jenuh tanah yang semakin menurun dengan menurunnya posisi pada lereng. 
Tabel 1. Data sifat fisik tanah

\begin{tabular}{|c|c|c|c|c|c|c|c|}
\hline \multirow[b]{2}{*}{ Lokasi } & \multirow[b]{2}{*}{ Lereng } & \multirow{2}{*}{$\begin{array}{c}\text { Bulk Density } \\
\left(\mathrm{g} \mathrm{cm}^{-3}\right)\end{array}$} & \multirow{2}{*}{$\begin{array}{c}\text { Porositas } \\
(\%) \\
\end{array}$} & \multicolumn{3}{|c|}{ Pori Drainase (\% volume) } & \multirow{2}{*}{$\begin{array}{c}\text { Rata-rata } \\
\text { Porositas } \\
\text { (\%) }\end{array}$} \\
\hline & & & & $\begin{array}{c}\text { Sangat } \\
\text { Cepat }\end{array}$ & Cepat & Lambat & \\
\hline \multirow{3}{*}{ Blok1 } & atas & 1.07 & 59.8 & 16.0 & 4.56 & 6.05 & \multirow{3}{*}{57.7} \\
\hline & tangah & 1.14 & 56.8 & 6.24 & 14.6 & 4.71 & \\
\hline & bawah & 1.15 & 56.6 & 10.6 & 4.6 & 5.42 & \\
\hline \multirow{3}{*}{ Blok 2} & atas & 1.11 & 58.2 & 10.5 & 9.08 & 4.04 & \multirow{3}{*}{56.2} \\
\hline & tangah & 1.12 & 57.8 & 7.66 & 13.9 & 6.22 & \\
\hline & bawah & 1.25 & 52.7 & 8.65 & 12.7 & 2.72 & \\
\hline \multirow{3}{*}{ Blok 3} & atas & 0.93 & 64.8 & 15.9 & 18.5 & 5.28 & \multirow{3}{*}{62.1} \\
\hline & tangah & 0.99 & 62.6 & 11.4 & 12.4 & 9.73 & \\
\hline & bawah & 1.09 & 58.9 & 11.6 & 17.7 & 4.85 & \\
\hline
\end{tabular}

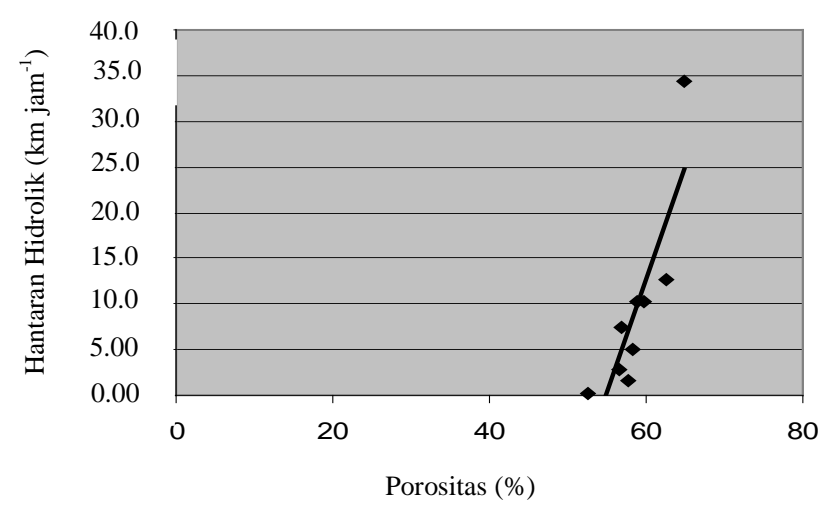

Gambar 2. Hubungan hantran hidrolik dengan porositas

Terdapat hubungan linier antara porositas tanah dengan hantaran hidrolik jenuh (Gambar 2). Semakin besar porositas tanah, maka hantaran hidrolik jenuh semakin besar. Hantaran hidrolik jenuh tanah dengan porositas tanah akan memiliki hubungan yang searah, peningkatan porositas tanah akan meningkatkan pula hantaran hidrolik jenuh tanahnya.

\section{Hantaran Hidrolik pada Gawangan mati, Piringan dan Jalan pikul}

Hasil pengukuran memperlihatkan bahwa rataan dari 3 blok, hantaran hidrolik jenuh tanah tertinggi terdapat pada lokasi gawangan mati $\left(13.8 \mathrm{~cm} \mathrm{jam}^{-1}\right)$ kemudian diikuti oleh lokasi piringan $\left(7.82 \mathrm{~cm} \mathrm{jam}^{-1}\right)$, dan yang memiliki nilai terendah adalah pada lokasi lahan berupa jalan pikul (6.55) (Tabel 2).

Gawangan mati memiliki nilai hantaran hidrolik jenuh tertinggi karena kondisi tanah pada daerah ini tidak terganggu oleh aktifitas fisik maupun kimia apapun. Selain itu adanya Legum Cover Crop (LCC) dapat meningkatkan nilai hantaran hidrolik jenuh tanah yang disebabkan oleh banyaknya perakaran dari LCC maupun peningkatan cadangan bahan organik dalam tanah. LCC juga mengurangi energi tumbukan butir hujan ke permukaan tanah sehingga kemantapan agregat tanah dapat tetap terjaga.

Perakaran dari LCC ini dapat meningkatkan aktifitas mikro organisme tanah yang mengakibatkan terbentuknya porositas tanah yang baik. Tajuk tanaman kelapa sawit juga mempengaruhi besarnya energi tumbukan butir hujan terhadap tanah. Dengan adanya tajuk, butir hujan akan tertahan oleh tajuk sebelum menyentuh tanah sehingga energinya akan berkurang.
Tabel 2. Nilai hantaran hidrolik pada berbagai jenis lokasi lahan

\begin{tabular}{llcl}
\hline & Lokasi & Nilai K $\left(\mathrm{cm} \mathrm{jam}^{-1}\right)$ & Kelas \\
\hline \multirow{3}{*}{ Blok 1 } & Piringan & 6.96 & Agak cepat \\
& Jalan pikul & 5.30 & Sedang \\
& Gawangan mati & 8.05 & Agak cepat \\
\multirow{3}{*}{ Blok 2 } & Piringan & 2.51 & Agak lambat \\
& Jalan pikul & 1.55 & Agak lambat \\
& Gawangan mati & 2.94 & Sedang \\
Blok 3 & Piringan & 14.0 & Cepat \\
& Jalan pikul & 12.8 & Cepat \\
& Gawangan mati & 30.4 & Sangat cepat \\
\hline
\end{tabular}

Gawangan mati memiliki nilai hantaran hidrolik jenuh tertinggi karena kondisi tanah pada daerah ini tidak terganggu oleh aktifitas fisik maupun kimia apapun. Selain itu adanya Legum Cover Crop (LCC) dapat meningkatkan nilai hantaran hidrolik jenuh tanah yang disebabkan oleh banyaknya perakaran dari LCC maupun peningkatan cadangan bahan organik dalam tanah. LCC juga mengurangi energi tumbukan butir hujan ke permukaan tanah sehingga kemantapan agregat tanah dapat tetap terjaga.

Perakaran dari LCC ini dapat meningkatkan aktifitas mikro organisma tanah yang mengakibatkan terbentuknya porositas tanah yang baik. Tajuk tanaman kelapa sawit juga mempengaruhi besarnya energi tumbukan butir hujan terhadap tanah. Dengan adanya tajuk, butir hujan akan tertahan oleh tajuk sebelum menyentuh tanah sehingga energinya akan berkurang.

Piringan memiliki nilai hantaran hidrolik jenuh tanah lebih kecil dibandingkan gawangan mati namun masih lebih besar jika dibandingkan dengan jalan pikul. Pemupukan yang dilakukan 2 kali dalam setahun di piringan mengakibatkan tanah menjadi padat. Selain itu tidak adanya penutup lahan pada piringan juga mempengaruhi pemadatan tanah, akibat butir hujan yang lolos dari tajuk langsung mengenai permukaan tanah sehingga mengakibatkan hancurnya agregat tanah. Tidak adanya penutup lahan juga berpengaruh kepada sedikitnya cadangan bahan organik tanah.

Nilai hantaran hidrolik jenuh tanah paling rendah terdapat pada jalan pikul. Hal ini dapat disebabkan oleh aktifitas fisik manusia, berupa pengangkutan hasil panen yang menggunakan sepeda melalui jalan-jalan ini. Panen yang dilakukan terus menerus tiap minggu semenjak kelapa sawit berumur 5 tahun hingga sekarang cenderung membuat tanah lebih padat dari pada keadaan asalnya. 


\section{Hantaran Hidrolik Jenuh Tanah pada Berbagai Posisi Lereng}

Areal pengukuran berdasarkan perbedaaan posisi pada lereng dibagi menjadi tiga bagian yaitu lokasi atas, tengah, dan bawah. Perbedaan posisi ini juga menyebabkan perbedaan hantaran hidrolik jenuh tanah. Secara umum lereng atas memiliki hantaran hidrolik jenuh paling besar (15.4 $\left.\mathrm{cm} \mathrm{jam}^{-1}\right)$, kemudian lereng tengah dan bawah (8.39 dan $4.40 \mathrm{~cm} \mathrm{jam}^{-1}$ ) (Tabel 3).

Tabel 3. Nilai hantaran hidrolik jenuh pada berbagai posisi lereng

\begin{tabular}{cccc}
\hline & \multicolumn{3}{c}{ Bagian Lereng } \\
\cline { 2 - 4 } Lokasi & Atas & Tengah & Bawah \\
\cline { 2 - 4 } & \multicolumn{3}{c}{ cm jam $^{-1}$} \\
\hline Blok 1 & 10.2 & 7.35 & 2.74 \\
Blok 2 & 5.08 & 1.65 & 0.27 \\
Blok 3 & 34.3 & 12.7 & 10.2 \\
\hline
\end{tabular}

Perbedaan nilai hantaran hidrolik jenuh ini disebabkan oleh kedalaman solum tanah yang berbeda. Tanah bagian atas memiliki solum yang lebih dalam dibandingkan dengan tanah bagian tengah dan bawah. Pada tanah bagian atas kedalaman solum tanah adalah > $110 \mathrm{~cm}$ sedangkan pada tanah bagian bawah kedalaman solumnya adalah $50 \mathrm{~cm}$. Hal ini memungkinkan air untuk masuk jauh kedalam tanah sehingga tanah akan lama jenuh. Selain itu perbedaan posisi juga menyebabkan pergerakan air dari tanah bagian atas ke tanah bagian bawah, sehingga kadar air pada daerah atas akan lebih rendah jika dibandingkan dengan daerah di bawahnya.

\section{SIMPULAN}

bahwa:

Dari penelitian ini dapat diambil kesimpulan

1. Pada perkebunan kelapa sawit hantaran hidrolik jenuh tanah tertinggi berada pada lokasi lahan berupa gawangan mati dan terendah berupa jalan pikul. Hal ini disebabkan karena pada gawangan mati struktur tanah relatif baik dibandingkan dengan pada piringan dan jalan pikul.

2. Hantaran hidrolik yang tinggi berguna untuk meresapkan air sebanyak-banyaknya ke dalam profil tanah. Semakin banyak air meresap ke dalam profil tanah maka semakin banyak air yang dapat disimpan di dalam profil tanah untuk keperluan pertumbuhan dan produksi tanaman. Pada lokasi dimana hantaran hidrolik rendah, seperti jalan pikul dan piringan maka perlu dilakukan cara lain untuk meningkatkan resapan air, misalnya rorak.

3. Hantaran hidrolik jenuh pada lereng atas lebih tinggi dari lereng bawah. Hal ini disebabkan oleh karena solum pada lereng bawah lebih dangkal.
4. Pada semua lokasi, semakin tinggi porositas total dan jumlah pori drainase sangat cepat dan cepat maka hantaran hidrolik jenuh semakin tinggi.

\section{SARAN}

Perlu diadakan penelitian lebih lanjut mengenai pengaruh peningkatan hantaran hidrolik jenuh tanah terhadap cadangan air bawah tanah.

\section{DAFTAR PUSTAKA}

Baver, L.D. 1959. Soil Physic. $3^{\text {rd }}$ ed John Willey and Sons, inc., New York.

Fauzi, Y., Y.E. Widiastuti, I. Satyawibawa, dan R. Hartono. 2002. Kelapa Sawit. Edisi Revisi. Penebar Swadaya. Depok.

Murtilaksono, K., H.H. Siregar, W. Darmosakoro. 2007. Water balance model in oil palm plantation. $J$. Penelitian Kelapa Sawit, 15:21-35.

Murtilaksono, K., W. Darmosarkoro, E.S. Sutarta, H.H. Siregar, Y. Hidayat, and M.A. Yusuf. 2011. Feasibility of soil and water conservation techniques on Oil Palm Plantation, J. Agrivita, Vol 33 No 1, Februari. hlm. 63-69.

Pahan, I. 2008. Panduan Lengkap Kelapa Sawit: Manajemen Agribisnis dari Hulu hingga Hilir. Penebar Swadaya. Jakarta.

Sunarti, N. Sinukaban, B. Sanim, S.D. Tarigan. 2008. Konversi hutan menjadi lahan usaha tani karet dan kelapa sawit serta pengaruhnya terhadap aliran permukaan dan erosi tanah di DAS Batang Pelepat, Jambi. J. Tanah Tropika, 13:253-260.

Tim Faperta IPB-PPKS Medan. 2006. Teknik peresapan air bebas aliran permukaan dalam upaya peningkatan produksi kelapa sawit. Laporan Penelitian Tahap I. Fakultas Pertanian. Institut Pertanian Bogor. Bogor.

Yahya, S. 1990. Budidaya Kelapa Sawit (Elaeis guineensis Jacq). Fakultas Pertanian. Institut Pertanian Bogor. Bogor. 